\title{
Analysis of Influence of MOOC for Development of Higher Education in China
}

\author{
Kun $\mathrm{Wu}^{1, \mathrm{a}^{*}}$ and Miao Shang ${ }^{2, \mathrm{~b}}$ \\ ${ }^{1,2}$ Mechanical and electrical technology department, Xijing University, Xi'an, China \\ a342752260@qq.com, ${ }^{\text {b } 445700839 @ q q . c o m ~}$
}

Keywords: Higher education; MOOC course; Curriculum construction; Teaching management

\begin{abstract}
The development of MOOC impacts the traditional teaching mode of higher education. In this article, combining with the existing MOOC platform and class instance, and the research platform, massive open online courses with specific course content and the user study, on the basis of exploring the development situation of MOOC. Combining our country's higher education, which MOOC of our country's higher education management, course builders and the influence of the learner and enlightenment was analyzed.
\end{abstract}

\section{Introduction}

MOOC storm swept across the world, the development of the MOOC MOOC an upsurge in learning and research. Sydney institute of Sui Fai John Mak according to the different theoretical basis for the MOOC is divided into five categories, namely teaching socialist MOOC, MOOC of cognitivism, constructivism MOOC, social constructivism of MOOC, and associated MOOC [iai. According to the different emphasis of each MOOC course design, will be divided into MOOC MOOC based on social network, based on task MOOC and content-based MOOC [1]. LisaMXane think all MOOC classification is not good or bad, there is no comprehensive and one-sided. The purpose of these courses is not so much in the open network environment of distributed learning course content and skills, rather than learn social skills such as communication.

Now has been approved by the classification is based on the associated socialist cMOOC and xMOOC based on behaviorism. Based on the correlation of socialism cMOOC advocated participants thoughts are linked together, the participants through discussion, interactive learning methods so as to obtain personalized knowledge construction and ultimately formed in knowledge network emergent curriculum group learning path. The MOOC mode, the starting point of learning resources is a teacher, the student learning center was conducted over resources to explore. CMOOC supporters, Canadian scholar "George simmons said:" our MOOC model (cMOOC) emphasize innovation, creativity, autonomy and social network learning. The Coursera model (xMOOC) is a more traditional learning way. Through the video display, quizzes and tests. "Marc Bousquet concluded:" good lesson (cMOOCs) for the most prominent place lies in the social dimension of support learning and active practice, for example, knowledge production and knowledge rather than consumption. "The MOOC of the three pillars of organizations is the typical representative of xmooc [2].

\section{Effects of Course Builder for MOOC}

Diversified of Education Evaluation Way. At present, higher education is in a course system reconstruction, learning and teaching mode reform and education supply mode transition phase. Among them, the teaching and learning are complementary to each other, to change the way of teaching and learning style changes to match, teaching content, teaching objectives and teaching evaluation ways will need to follow the trend of change [3].

In the analysis of three big platform evaluation forms to Coursera courses are adopted peer evaluation platform, and evaluate the specific course instance way analysis, found that for different teaching forms, course content, the evaluation mode is not the same. Process evaluation and the way 
of combination of summative evaluation, process evaluation methods including assignments, exercises, and test after class at ordinary times, learning logs, BBS participation, demonstration, operation, etc., section contains the midterm and final exam evaluation, but in smaller as a proportion of the final grade (see table 3.5). To pay attention to the process of higher education advocates the evaluation method is fit, for course builder, in curriculum setting, teaching evaluation form can refer to similar to the nature of the course of MOOC evaluation way, pay attention to learning outcomes at the same time pay more attention to the learning process [4]. Summative evaluation of course also can refer to have a variety of forms, such as the grade evaluation and peer evaluation, teacher evaluation, etc. The peer evaluation forms allow learners to student role outside, to the teacher's Angle of view to see the students the task progress and result of learning evaluation way of from classmates tasks at the same time also can know a different point of view for understanding knowledge, worth builder of institutions of higher education courses to learn from. Scholars age distribution as shown in Fig. 1.

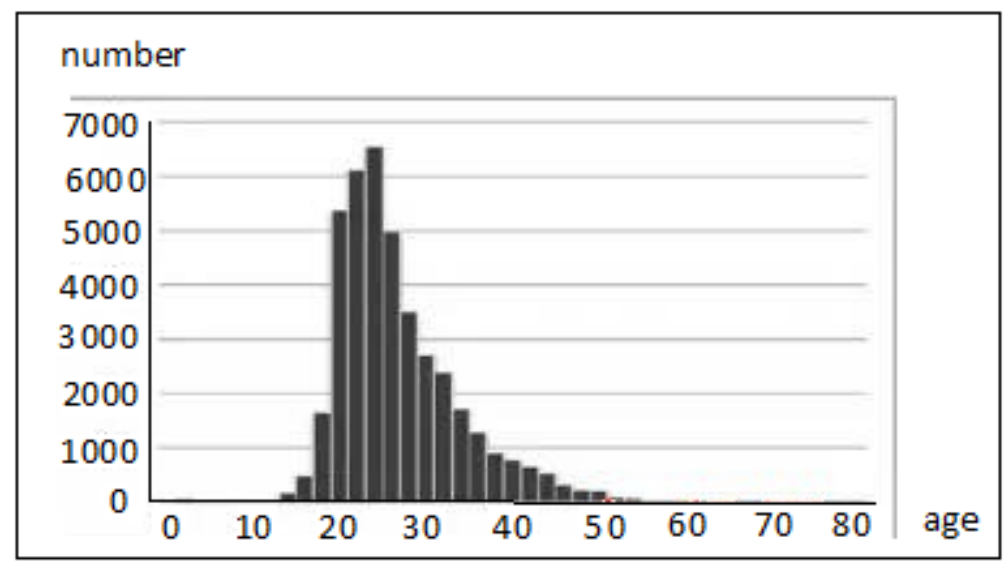

Figure 1. scholars age distribution

Attaches Great Importance to Teaching Feedback. MOOC of curriculum resources and curriculum platform is needed to open; JT? Put, in open course, learners of different learning experiences can help teachers to deepen course teaching content, can be from a different perspective on curriculum content of its recommendations, through coursework feedback of students' individual differences can also strengthen the function of homework teaching, learners to participate in the BBS published free personal opinion. Three forms of interactive platform, BBS communication form is a teacher the first course, learners share personal learning experience to understand that the way with questions in the course short video course is more popular than for a long time. Large-scale course feedback can help teachers to pinpoint the problems, learners encounter targeted to solve the key problem [5].

In addition, of course the user survey found that the course such problems as lack of real-time feedback and communication difficulties still exist. Course also requires that the teacher open mentality, and learners' interaction to give feedback in time, allow learners make different points of view, if course learners are not satisfied with this course, allowing freedom to withdraw without penalty, no limits instructor. For builders and course teachers, inevitably need to ensure the quality of curriculum, promoting quality education resources construction, focus on problems in the process of teaching and give feedback in time.

Customized of Course Platform. At present, the MOOC learners in learning involved in course exist two main problems, one is the language problem, now in addition to the Chinese mainland and Taiwan university offers courses in Chinese video, most of the other countries is to use English teaching, for professional stronger course, learners of English listening, speaking, reading and writing to a large extent affected the learning effects. Another is the problem website platform, part of the learner repeatedly mentioned in the discussion forum to share the user experience. Three platforms 
run from the basic requirements, common networked computer to be able to meet the requirements, but the course video on YouTube, cyber and geographical restrictions, some resources can't see, also larger influence on learners' learning effect [6].

\section{Effects of Teaching Management for MOOC}

There are three main MOOC mainstream platform, but other countries or education institutions are r\&d MOOC platform established, such as Google's Open Course Builder School Open2Study, Australia, Japan, German iversity, such as platform, although Coursera platform provides Chinese platform, nut shell network also provide a Chinese learning community - MOOC college, that in order to facilitate the MOOC learners in our country, promote the MOOC sustainable development in our country, have independent intellectual property rights, belong to China's independent platform, is Course Builder faces a challenge [7].

(1) The education internationalization. The massive open online courses in emerging things MOOC big popular era, today's higher education world powers are mainly European and American countries, and the famous universities in these countries is also promote the construction of MOOC's main force, this will make university faces new challenges in other countries, especially countries international education influence is weak. This period is the development of educational opportunity, need to clearly grasp the key period [8]. Traditional concept of education, higher education is considered to be the end of the education ladder level, a student from entering the university, have decided to accept the education level, from the learners to get out of the university, means that the students receive formal education has come to an end, but, this kind of education mode can change now, education is no longer just the inside of the institutions of higher learning, education is becoming more and more open now, the campus is becoming more and more blurred border of higher education, the rise of MOOC also contributed to higher education out of the campus.

(2) Knowledge education serves the society. Education is to enable learners to increase knowledge and skills, promote all-round development of body and mind. Knowledge is a service to the society. Course learners and builders have the national boundary, but knowledge is no national boundaries. From three platform registration and a business model analysis results showed that three big platform for free, all course learners enjoy free resources. Through the support of venture capital and nonprofit education organizations to maintain platform courses for free and open, make the world more learners have access to the curriculum platform provides knowledge, to better serve the society. At duke university in announcing to join Coursera platform on its clear it is the support of university development, the knowledge to serve the society as a strategic goal.

For higher education managers, can provide some opportunities for learners, free or for a fee or other forms, open the doors of higher education courses, open learning, open platform, open, open evaluation together form the open learning environment, allowing more learners have entering society return to university to study further, also continues to evolve and open course, constantly updated [9].

(3)The university-enterprise cooperation training talents. Of the three major mainstream MOOC platform, has the form part of the curriculum is based on the project, project curriculum content and the enterprise directly related to exercise of the learner's ability to operate at the same time also provide a convenient choosing talents for the enterprise. As can be seen from the three platform partners, Coursera platform started learning center program provides students with access to the Internet and online education resources of physical space; with new technology and science and technology entrepreneurship as the core theme of Digital October center, focus on entrepreneurship. Udacity platform and many high-tech companies such as Google, NVIDIA, Microsoft, etc. Through the course of learning, improve self work skills, able to work faster into the role. Higher education in our country, there is also a school and the case of running a school unitedly of the enterprise, but do more successful cooperation in running schools model are numbered [10].

Tsinghua university President in an interview with time put forward "supported by government, colleges and universities dominant, enterprise participation of school-running mode can provide guidance for higher education to cultivate talents. Higher education managers can draw lessons from 
successful MOOC university-enterprise cooperation form, will be excellent enterprise resources and the education of institutions of higher learning resources overall planning, comprehensive applied to engineering education practice and learners to cultivate the students' innovation ability, make higher education learners employability skills, alleviate the employment pressure [11].

\section{MOOC Effects on College Students}

MOOC mode of college students and the important influence in learning, learning experience.

The Study way Transformation. Higher education does not mean the end of accept education opportunity came to an end, in a learning society requires a lifelong learning, learners can MOOC curriculum and STEM the relevance of education teaching is a factor of learners to participate in the course. Can be seen in the user survey results analysis is most main is involved in the course of higher education of undergraduate and graduate students (see Fig. 4.1 and Fig. 4.2), while the learners of higher education learners are not necessarily MOOC, also can serve as tutors, cooperation with more learners or education institutions performed to academic research, the formation of sustainable development. Research MOOC way of teaching and learning style can also be looking for personalized learning.

The Learning Experience to Share. Course provides platform allows learners in the creative Commons (CC) under the premise of high quality education resources sharing course. Three big platform for curriculum knowledge copyright are specified, also in terms of registration statement learners need to follow the rules, such as academic integrity, intellectual copyright protection, respect for others, etc. In the peer evaluation plate special instructions learners banned from other achievements, set the "report" button to supervise and urge learners to academic integrity. When learners to share knowledge and learning experience, also need to follow the same principle.

\section{Conclusions}

MOOC influence the development of the traditional teaching mode of higher education. In this article, combining with the existing MOOC platform and course as an example, the research platform, massive open online courses with specific course content and the user study, on the basis of exploring the development situation of MOOC. Combining our country's higher education, MOOC of our country's higher education management, course builders and the influence of the learner and enlightenment was analyzed. The development of higher education in our country's journey, the MOOC has a certain role in promoting. At the same time, the MOOC also needs to be more reasonable to adapt to China's national conditions.

\section{References}

[1] L.Yuan, Stephen Powell, H.L. Ma: International Status Quo Analysis of Massive Open Online Courses Closed, Vol. 84(2013) No. 3.

[2] Benoit Minogue: Higher Education Spending and Output-Complexity of Relationship, Peking University Education review, Vol. 2 (2013), 60.

[3] B.C.Ji:Our Country's Higher Education Scale Forecast Analysis in 2020, Vol. 1 (2011) No. 1, p. 305.

[4] Z.Wang,J.X.Tian: Inheriting Hin for Class in Our Country the Development of the SWOT Analysis, Journal of the new curriculum (below), Vol.7(2013)No.7.

[5] W.X.Cai,J.Wang: The First Year of MOOC, Vol.4(2012),P.16-18.

[6] H.Y.Liu: U DP Proportion Higher Education and Social Policy Research, Vol. (2012), P. 27-28. 
[7] J.B.Wang, H.T.Yang::New Field of Overseas Investment-New Trend of Transnational Higher Education (DongYue Review, China, 2012)

[8] Henry m. levin. Education How to Adapt to Future-Background of American Education, Peking University Education Review, Vol. 2 (2013), p. 2-3.

[9] P.Wang: New Development and Application of Large-Scale Online Open Courses, Vol. 19(2013) No.1.

[10] G.P.Feng: Transnational Education - International Comparative Study (Shanghai People's Publishing House, China, 2010)

[11]T.Wang,Q.Li: MOOC - A Giant Open Courses of Unicom Based Model, Vol.19(2013)No.3. 